\title{
Spectral correlations in some substituted styryl (E)-4-((2-oxopropyl) diazenyl) benzoic acids
}

\author{
V. Sathiyendiran ${ }^{1}$, K. G. Sekar ${ }^{2, *}$, G. Thirunarayanan ${ }^{3}$, R. Arulkumaran ${ }^{4}$, \\ R. Sundararajan ${ }^{4}$, D. Kamalakkannan ${ }^{4}$, R. Suresh ${ }^{4}$, V. Manikanadan ${ }^{4}$, \\ R. Vijayakumar ${ }^{4}$, G. Vanangamudi ${ }^{4}$ \\ ${ }^{1}$ Department of Chemistry, Sourastra College, Madurai - 625 004, India \\ ${ }^{2}$ Department of Chemistry, National College, Tiruchirappalli - 620001 , India \\ ${ }^{3}$ Department of Chemistry, Annamalai University, Annamalainagar - 608 002, India \\ ${ }^{4} \mathrm{PG} \&$ Research Department of Chemistry, Government Arts College, \\ C-Mutlur - 608 102, Chidambaram, India \\ *E-mail address: drkgsekar@yahoo.co.in
}

\begin{abstract}
A series of titled compounds were prepared and analyzed their purities by literature method. The infrared and NMR spectral group frequencies of the compounds were assigned and correlated with Hammett substituent constants, F and $\mathrm{R}$ constants using single and multi linear regression analysis. From the results of statistical analysis, the effect of substituents on the above spectral frequencies was discussed.
\end{abstract}

Keywords: Oxo-propyl diazenyl benzoic acid chalcones; IR spectra, NMR spectra, Hammett equation; Regression analysis

\section{INTRODUCTION}

Currently, scientists and chemists were paid more attention for utilizing the spectroscopic data for studying QSAR, QPR and QSR of organic molecules [1-10]. From these studies, the ground state configuration and the effect of substituents on the molecule have been evaluated [11]. Also the spectroscopic data were applied for predicting the behavior of electrochemical redox potential correlation [12], reaction transition state equilibrium [13], $\mathrm{IC}_{50}$ value of drug molecule correlations [14], qualitative and quantitative estimation [15], enol-enone tautomerism [16]. Generally chalcones possess important biological activities such as anti-microbial [3], antidepressants [17], antiplosmodial [18], antiaids [19] and insect antifeedant activities [20-22]. Infrared spectra is a good instrument for analyzing the structure of organic molecules [11], qualitative and quantitative measurements [15], geometrical isomers, s-cis and s-trans equilibration of unsaturated ketones, anti- and gauche- form of acyl compounds [1-10]. The NMR spectroscopic data were applied for predicting spatial arrangements of the $E$ or $Z$ isomers and conformers in unsaturated ketones, pyrazolines, n-acetyl pyrazoline, thiopyrazoline and it derivatives [6,7]. The effect of 
substituents on the above molecular conformations also studied through Hammett substituent constants, F and R parameters [8]. Thirunarayanan have studied QSAR and QPR study with spectral frequencies in thiadiazole-2-amines [8]. Joseph and his co-workers have studied the effect of substituents on dimethyl phenyl chalcones by Hammett equation with spectral data [23]. Sekar and Thirunarayanan have evaluated the spectral correlation in pyrazoline derivatives [24]. The substituent effects on oxazine-2-amines were studied using spectral data using single and multi-regression analysis [25]. Kamalakkannan et al., have investigated the substituent effects on 2-indolyl chalcones by electrochemical redox potential with Hammett equation [26]. Kalyanasundaram et al., have studied the effect of substituents on phenoxyphenyl chalcones through IR and NMR spectroscopic data [10]. Within the above view there is no reported in the literature for the QSAR and QPR study of substituted styryl (E)-4-((2-oxopropyl) diazenyl) benzoic acids in the past. Therefore the authors have taken efforts for studying the effect of substituent on the IR and NMR spectral data through Hammett equation using linear regression analysis.

\section{EXPERIMENTAL}

\section{1. General}

All chemicals and solvents used in this present study were purchased from SigmaAldrich and Merck companies. The infrared spectra of all chalcones were recorded in SHIMADUZ Fourier Transform IR spectrophotometer using $\mathrm{KBr}$ disc. The NMR spectra of all compounds have been recorded in BRUKER AV 400 type spectrometer, using $\mathrm{CDCl}_{3}$ as a solvent, $400 \mathrm{MHz}$ frequency was applied for recording $1 \mathrm{H}, 100 \mathrm{MHz}$ for ${ }^{13} \mathrm{C} \mathrm{NMR}$ spectra, taking TMS as standard.

\section{2. Synthesis of substituted styryl (E)-4-((2-oxopropyl) diazenyl) benzoic acid derivatives.}

The titled chalcones were prepared and their purities were analyzed by the literature method [27]. The general structure of the chalcones is illustrated in Fig. 1.



$\mathrm{X}=\mathrm{H}, 3-\mathrm{Br}, 2-\mathrm{Cl}, 4-\mathrm{Cl}, 2-\mathrm{OH}, 4-\mathrm{OH}, 4-\mathrm{OCH}_{3}, 2-\mathrm{NO}_{2}, 4-\mathrm{NO}_{2}$

Fig. 1. Structure of substituted styryl (E)-4-((2-oxopropyl) diazenyl) benzoic acids. The analytical and spectroscopic data of selective compounds are given below.

3-Bromostyryl (E)-4-((2-oxopropyl) diazenyl) benzoic acid: m.p. 143-144 ${ }^{\circ} \mathrm{C}$, IR $(\mathrm{KBr}, v$, 4000-400 cm $\left.{ }^{-1}\right): 1715\left(\mathrm{CO}_{\text {acid }}\right), 1686\left(\mathrm{CO}_{\text {s-cis, keto }}\right), 1676\left(\mathrm{CO}_{\text {s-trans, keto }}\right), 1483(\mathrm{~N}=\mathrm{N}) ;{ }^{1} \mathrm{HNMR}$ $(\delta, \mathrm{ppm}): 6.514\left(d, 1 \mathrm{H}, \mathrm{H}_{\alpha}\right) 6.743\left(d, 1 \mathrm{H}, \mathrm{H}_{\beta}\right), 3.712\left(s, 2 \mathrm{H}, \mathrm{CH}_{2}\right) ;{ }^{13} \mathrm{CNMR}(\delta, \mathrm{ppm}): 193.04$ 
$\left(\mathrm{CO}_{\text {acid }}\right), 171.91\left(\mathrm{CO}_{\text {keto }}\right), 124.01\left(\mathrm{C}_{\alpha}\right), 143.02\left(\mathrm{C}_{\beta}\right)$; M.F. $\mathrm{C}_{17} \mathrm{H}_{13} \mathrm{BrN}_{2} \mathrm{O}_{3}$; M. W. 373; Mass $(\mathrm{m} / \mathrm{z}): 373\left[\mathrm{M}^{+}\right], 375\left[\mathrm{M}^{2+}\right]$.

4-Chlorostyryl (E)-4-((2-oxopropyl) diazenyl) benzoic acid: m.p. $126-127{ }^{\circ} \mathrm{C}$, IR $(\mathrm{KBr}, v$, 4000-400 $\left.\mathrm{cm}^{-1}\right): 1713\left(\mathrm{CO}_{\text {acid }}\right), 1683\left(\mathrm{CO}_{\text {s-cis, keto }}\right), 1662\left(\mathrm{CO}_{\text {s-trans, keto }}\right), 1487(\mathrm{~N}=\mathrm{N}) ;{ }^{1} \mathrm{H} \mathrm{NMR}$ $(\delta, \mathrm{ppm}): 6.361\left(d, 1 \mathrm{H}, \mathrm{H}_{\alpha}\right), 6.517\left(d, 1 \mathrm{H}, \mathrm{H}_{\beta}\right), 3.3 .167\left(s, 2 \mathrm{H}, \mathrm{CH}_{2}\right) ;{ }^{13} \mathrm{C} \mathrm{NMR}(\delta, \mathrm{ppm})$ : $197.72\left(\mathrm{CO}_{\text {acid }}\right), 170.97\left(\mathrm{CO}_{\text {keto }}\right), 123.71\left(\mathrm{C}_{\alpha}\right), 143.11\left(\mathrm{C}_{\beta}\right)$; M. F. $\mathrm{C}_{17} \mathrm{H}_{13} \mathrm{ClN}_{2} \mathrm{O}_{3}$; M. W. 329; Mass (m/z): $329\left[\mathrm{M}^{+}\right], 331\left[\mathrm{M}^{2+}\right]$.

\section{RESULTS AND DISCUSSION}

In the present investigations, the authors have studied the effect of substituents on the IR and NMR spectral group frequencies of substituted styryl (E)-4-((2-oxopropyl) diazenyl) benzoic acid derivatives using Hammett equation [1-12,23-29] with Hammett substituent constants and $\mathrm{F}$ and $\mathrm{R}$ parameters [30].

\section{1. IR spectral study}

The assigned $\mathrm{CO}_{\text {acid }}, \mathrm{CO}_{\text {s-cis, keto }}, \mathrm{CO}_{\text {s-trans, keto }}$ and $\mathrm{N}=\mathrm{N}$ stretching frequencies $\left(\mathrm{v}, \mathrm{cm}^{-1}\right)$ of prepared substituted styryl (E)-4-((2-oxopropyl) diazenyl) benzoic acid derivatives were presented in Table 1.

Table 1. The IR and NMR spectroscopic data of substituted styryl (E)-4-((2-oxopropyl) diazenyl) benzoic acids.

\begin{tabular}{|c|c|c|c|c|c|c|c|c|c|c|c|c|}
\hline \multirow[b]{2}{*}{ No. } & \multirow[b]{2}{*}{ X } & \multicolumn{4}{|c|}{$\operatorname{IR}\left(v, \mathrm{~cm}^{-1}\right)$} & \multicolumn{3}{|c|}{${ }^{1} \mathrm{HNMR}(\delta, \mathrm{ppm})$} & \multicolumn{4}{|c|}{${ }^{13} \mathrm{CNMR}(\delta, \mathrm{ppm})$} \\
\hline & & 己 & 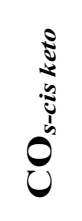 & 己. & $\underset{\mathrm{Z}}{\mathrm{Z}}$ & $\ddot{0}$ & $\stackrel{n}{=}$ & $\bar{U}$ & ర్ & 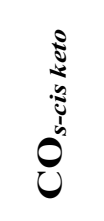 & $u^{\circ}$ & $u^{\infty}$ \\
\hline 1 & $\mathrm{H}$ & 1713 & 1682 & 1668 & 1482 & 6.683 & 6.979 & 3.041 & 197.63 & 171.82 & 123.85 & 143.32 \\
\hline 2 & $3-\mathrm{Br}$ & 1715 & 1686 & 1676 & 1483 & 6.514 & 6.743 & 3.172 & 197.04 & 171.91 & 124.01 & 143.02 \\
\hline 3 & $2-\mathrm{Cl}$ & 1714 & 1690 & 1673 & 1484 & 6.481 & 6.881 & 3.092 & 198.03 & 171.17 & 124.93 & 143.14 \\
\hline 4 & $4-\mathrm{Cl}$ & 1713 & 1683 & 1662 & 1487 & 6.361 & 6.517 & 3.167 & 197.72 & 170.97 & 123.71 & 143.11 \\
\hline 5 & $2-\mathrm{OH}$ & 1711 & 1678 & 1654 & 1485 & 6.383 & 6.899 & 3.295 & 196.19 & 173.81 & 122.71 & 143.05 \\
\hline 6 & $4-\mathrm{OH}$ & 1709 & 1687 & 1664 & 1483 & 6.493 & 6.871 & 3.151 & 198.09 & $\begin{array}{l}175.77 \\
\end{array}$ & $\begin{array}{ll}123.81 \\
\end{array}$ & 142.75 \\
\hline 7 & $4-\mathrm{OCH}_{3}$ & 1710 & 1678 & 1660 & 1479 & 6.302 & 6.507 & 3.090 & 196.72 & 174.92 & 123.04 & 141.92 \\
\hline
\end{tabular}

These data have been correlated with Hammett substituent constants and $\mathrm{F}$ and $\mathrm{R}$ parameter using linear regression analysis [1-12,23-29]. In Infrared spectral correlation, the Hammett equation is taken in the form of

$$
v=\rho \sigma+v_{\mathrm{o}}
$$

where $v_{0}$ is the frequency for the parent member of the series. 
The results of statistical analysis [1-12,23-29] are presented in Table 2. From the Table 2 , the $\mathrm{CO}_{\text {acid }}\left(\mathrm{v}, \mathrm{cm}^{-1}\right)$ frequencies correlated satisfactorily with Hammett substituent constants, $\mathrm{F}$ and $\mathrm{R}$ parameters. The correlation of $\mathrm{CO}_{\text {s-cis keto }}\left(\mathrm{v}, \mathrm{cm}^{-1}\right)$ frequencies were correlated satisfactorily. The Hammett $\sigma, \sigma^{+}, \sigma_{\mathrm{R}}$ constants and $\mathrm{R}$ parameters correlated satisfactorily for $\mathrm{CO}_{s-\text { trans }}$ keto $\left(v, \mathrm{~cm}^{-1}\right)$ frequencies of substituted styryl $(E)-4-((2-$-oxopropyl $)$ diazenyl) benzoic acid derivatives. The Hammett $\sigma_{\mathrm{I}}$ constants and $\mathrm{F}$ parameter were fail in correlation with $\mathrm{CO}_{\text {s-trans }}$ keto $\left(\mathrm{v}, \mathrm{cm}^{-1}\right)$ frequencies. This is due to the absence of inductive and polar effect of substituents on the carbonyl frequencies and is associated with the resonance conjugative structure as shown in Fig. 2.

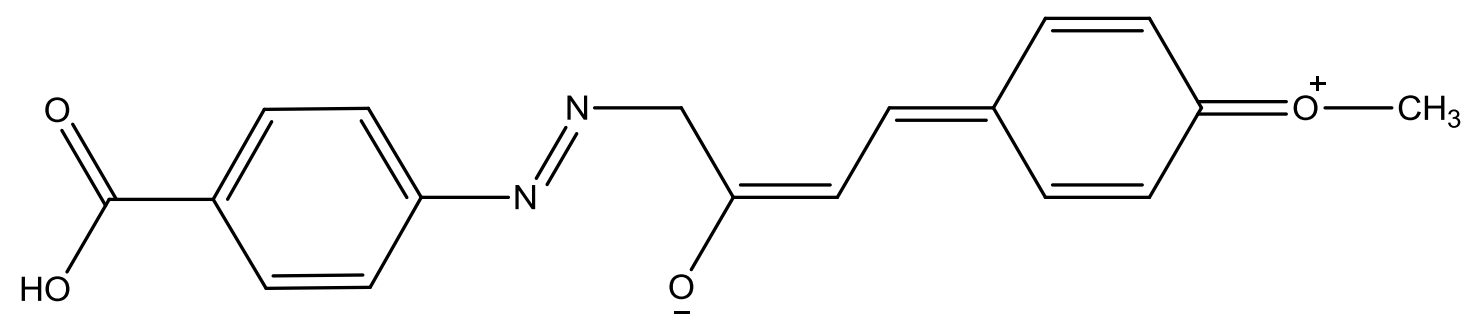

Fig. 2. The resonance and conjugative structure.

The $\mathrm{N}=\mathrm{N}\left(v, \mathrm{~cm}^{-1}\right)$ stretching frequencies of all compounds correlated satisfactorily with Hammett $\sigma$ constant and F parameter. The remaining Hammett $\sigma^{+}, \sigma_{\mathrm{R}}$ and $\sigma_{\mathrm{I}}$ constants and $\mathrm{R}$ parameters were fail in correlations. The failure in correlation was due to the ineffective polar, inductive and resonance effect of substituents and associated with the resonance conjugative structure as shown in Fig. 2. All correlations gave positive $\rho$ values. This means that the normal substituent effect operated in all systems.

Table 2. Results of statistical analysis of IR, ${ }^{1} \mathrm{H}$ NMR and ${ }^{13} \mathrm{C}-\mathrm{NMR}$ spectral values of substituted styryl (E)-4-((2-oxopropyl) diazenyl) benzoic acids with Hammett $\sigma, \sigma^{+}, \sigma_{\mathrm{I}}, \sigma_{\mathrm{R}}$ constants,

$\mathrm{F}$ and $\mathrm{R}$ parameters.

\begin{tabular}{|c|c|c|c|c|c|c|c|}
\hline Frequency & Constant & $\mathbf{r}$ & I & $\rho$ & $\mathbf{S}$ & n & $\begin{array}{l}\text { Correlated } \\
\text { derivatives }\end{array}$ \\
\hline \multirow{6}{*}{ 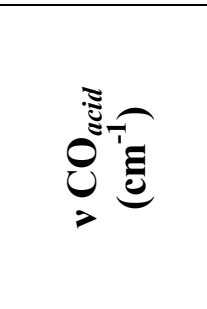 } & $\sigma$ & 0.906 & 1712.79 & 4.617 & 2.55 & \multirow{6}{*}{9} & \multirow{6}{*}{$\begin{array}{c}\mathrm{H}, 3-\mathrm{Br}, 2-\mathrm{Cl}, 4-\mathrm{Cl}, \\
\text { 2-OH, 4-OH, } \\
\text { 4-OCH }, 2-\mathrm{NO}_{2}, \\
4-\mathrm{NO}_{2}\end{array}$} \\
\hline & $\sigma^{+}$ & 0.905 & 1713.44 & 2.919 & 2.67 & & \\
\hline & $\sigma_{I}$ & 0.902 & 1710.58 & 7.681 & 2.80 & & \\
\hline & $\sigma_{R}$ & 0.905 & 1714.89 & 6.841 & 2.46 & & \\
\hline & $\mathrm{F}$ & 0.915 & 1710.39 & 8.043 & 2.41 & & \\
\hline & $\mathrm{R}$ & 0.919 & 1714.83 & 4.900 & 2.40 & & \\
\hline \multirow{6}{*}{ 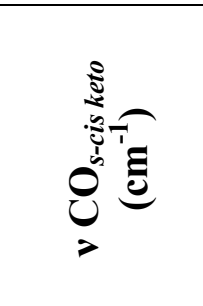 } & $\sigma$ & 0.971 & 1683.71 & 9.823 & 3.82 & \multirow{6}{*}{9} & \multirow{6}{*}{$\begin{array}{c}\mathrm{H}, 3-\mathrm{Br}, 2-\mathrm{Cl}, 4-\mathrm{Cl} \text {, } \\
\text { 2-OH, 4-OH, } \\
\text { 4-OCH } \mathrm{OCH}_{3}, 2-\mathrm{NO}_{2}, \\
4-\mathrm{NO}_{2}\end{array}$} \\
\hline & $\sigma^{+}$ & 0.970 & 1685.08 & 6.210 & 4.10 & & \\
\hline & $\sigma_{\text {I }}$ & 0.973 & 1677.94 & 19.118 & 3.96 & & \\
\hline & $\sigma_{R}$ & 0.968 & 1688.08 & 14.051 & 4.25 & & \\
\hline & $\mathrm{F}$ & 0.969 & 1677.77 & 19.205 & 4.23 & & \\
\hline & $\mathrm{R}$ & 0.962 & 1688.77 & 10.544 & 4.54 & & \\
\hline \multirow{4}{*}{ 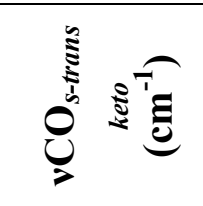 } & $\sigma$ & 0.958 & 1664.46 & 9.342 & 5.87 & \multirow{4}{*}{9} & \multirow{4}{*}{$\begin{array}{c}\mathrm{H}, 3-\mathrm{Br}, 2-\mathrm{Cl}, 4-\mathrm{Cl}, \\
\text { 2-OH, 4-OH, } \\
\text { 4-OCH}, 2-\mathrm{NO}_{2} \\
4-\mathrm{NO}_{2}\end{array}$} \\
\hline & $\sigma^{+}$ & 0.964 & 1665.71 & 9.066 & 5.51 & & \\
\hline & $\sigma_{\mathrm{I}}$ & 0.838 & 1661.26 & 12.240 & 7.15 & & \\
\hline & $\sigma_{R}$ & 0.962 & 1669.05 & 15.820 & 5.63 & & \\
\hline
\end{tabular}




\begin{tabular}{|c|c|c|c|c|c|c|c|}
\hline & $\mathrm{F}$ & 0.823 & 1662.63 & 8.532 & 7.00 & & \\
\hline & $\mathrm{R}$ & 0.963 & 1669.26 & 12.564 & 5.74 & & \\
\hline \multirow{6}{*}{ 劣 } & $\sigma$ & 0.957 & 1496.87 & 140.092 & 88.87 & \multirow{6}{*}{9} & \multirow{6}{*}{$\begin{array}{c}\mathrm{H}, 3-\mathrm{Br}, 2-\mathrm{Cl}, 4-\mathrm{Cl} \\
2-\mathrm{OH}, 4-\mathrm{OH}, \\
4-\mathrm{OCH}_{3}, 2-\mathrm{NO}_{2} \\
4-\mathrm{NO}_{2}\end{array}$} \\
\hline & $\sigma^{+}$ & 0.744 & 1515.51 & 73.502 & 97.63 & & \\
\hline & $\sigma_{\mathrm{I}}$ & 0.848 & 1427.51 & 234.024 & 95.46 & & \\
\hline & $\sigma_{R}$ & 0.849 & 1554.89 & 188.642 & 94.80 & & \\
\hline & $\mathrm{F}$ & 0.905 & 1414.96 & 261.942 & 89.23 & & \\
\hline & $\mathrm{R}$ & 0.817 & 1436.21 & 142.815 & 96.74 & & \\
\hline \multirow{6}{*}{ 홍 } & $\sigma$ & 0.917 & 6.483 & 0.332 & 0.13 & \multirow{6}{*}{9} & \multirow{6}{*}{$\begin{array}{c}\mathrm{H}, 3-\mathrm{Br}, 2-\mathrm{Cl}, 4-\mathrm{Cl}, \\
2-\mathrm{OH}, 4-\mathrm{OH}, \\
4-\mathrm{OCH}_{3}, 2-\mathrm{NO}_{2}, \\
4-\mathrm{NO}_{2}\end{array}$} \\
\hline & $\sigma^{+}$ & 0.916 & 6.529 & 0.207 & 0.15 & & \\
\hline & $\sigma_{\mathrm{I}}$ & 0.838 & 6.403 & 0.348 & 0.18 & & \\
\hline & $\sigma_{\mathrm{R}}$ & 0.928 & 6.656 & 0.107 & 0.10 & & \\
\hline & $\mathrm{F}$ & 0.837 & 6.394 & 0.364 & 0.18 & & \\
\hline & $\mathrm{R}$ & 0.976 & 6.657 & 0.461 & 0.12 & & \\
\hline \multirow{6}{*}{ 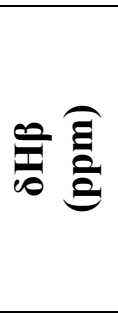 } & $\sigma$ & 0.848 & 6.803 & 0.256 & 0.20 & \multirow{6}{*}{9} & \multirow{6}{*}{$\begin{array}{c}\mathrm{H}, 3-\mathrm{Br}, 2-\mathrm{Cl}, 4-\mathrm{Cl}, \\
2-\mathrm{OH}, 4-\mathrm{OH}, \\
4-\mathrm{OCH}_{3}, 2-\mathrm{NO}_{2}, \\
4-\mathrm{NO}_{2}\end{array}$} \\
\hline & $\sigma^{+}$ & 0.849 & 6.831 & 0.177 & 0.20 & & \\
\hline & $\sigma_{\mathrm{I}}$ & 0.822 & 6.751 & 0.237 & 0.23 & & \\
\hline & $\sigma_{\mathrm{R}}$ & 0.905 & 6.927 & 0.421 & 0.20 & & \\
\hline & $\mathrm{F}$ & 0.828 & 6.721 & 0.314 & 0.22 & & \\
\hline & $\mathrm{R}$ & 0.848 & 6.931 & 0.325 & 0.20 & & \\
\hline \multirow{6}{*}{ 焉 } & $\sigma$ & 0.718 & 3.148 & 0.020 & 0.17 & \multirow{6}{*}{9} & \multirow{6}{*}{$\begin{array}{c}\mathrm{H}, 3-\mathrm{Br}, 2-\mathrm{Cl}, 4-\mathrm{Cl} \text {, } \\
\text { 2-OH, 4-OH, } \\
4-\mathrm{OCH}_{3}, 2-\mathrm{NO}_{2}, \\
4-\mathrm{NO}_{2}\end{array}$} \\
\hline & $\sigma^{+}$ & 0.805 & 3.152 & 0.071 & 0.04 & & \\
\hline & $\sigma_{\mathrm{I}}$ & 0.834 & 3.105 & 0.117 & 0.02 & & \\
\hline & $\sigma_{\mathrm{R}}$ & 0.827 & 3.137 & 0.075 & 0.03 & & \\
\hline & $\mathrm{F}$ & 0.486 & 3.081 & 0.181 & 0.16 & & \\
\hline & $\mathrm{R}$ & 0.725 & 3.137 & 0.075 & 0.16 & & \\
\hline \multirow{6}{*}{$\bigcup_{0}^{\stackrel{\Xi}{\Xi}}$} & $\sigma$ & 0.841 & 197.36 & 0.664 & 0.64 & \multirow{6}{*}{9} & \multirow{6}{*}{$\begin{array}{c}\mathrm{H}, 3-\mathrm{Br}, 2-\mathrm{Cl}, 4-\mathrm{Cl} \text {, } \\
\text { 2-OH, 4-OH, } \\
4-\mathrm{OCH}_{3}, 2-\mathrm{NO}_{2}, \\
4-\mathrm{NO}_{2}\end{array}$} \\
\hline & $\sigma^{+}$ & 0.831 & 197.45 & 0.418 & 0.65 & & \\
\hline & $\sigma_{\mathrm{I}}$ & 0.736 & 197.03 & 1.171 & 0.66 & & \\
\hline & $\sigma_{\mathrm{R}}$ & 0.905 & 197.76 & 1.495 & 0.57 & & \\
\hline & $\mathrm{F}$ & 0.817 & 196.17 & 1.131 & 0.63 & & \\
\hline & $\mathrm{R}$ & 0.900 & 198.13 & 2.714 & 0.59 & & \\
\hline \multirow{6}{*}{ 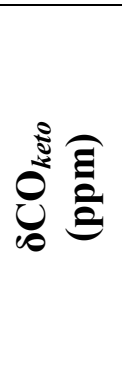 } & $\sigma$ & 0.671 & 173.49 & 0.388 & 2.23 & \multirow{6}{*}{9} & \multirow{6}{*}{$\begin{array}{c}\mathrm{H}, 3-\mathrm{Br}, 2-\mathrm{Cl}, 4-\mathrm{Cl}, \\
\text { 2-OH, 4-OH, } \\
\text { 4-OCH }, 2-\mathrm{NO}_{2}, \\
4-\mathrm{NO}_{2}\end{array}$} \\
\hline & $\sigma^{+}$ & 0.717 & 173.58 & 0.640 & 2.21 & & \\
\hline & $\sigma_{\mathrm{I}}$ & 0.725 & 172.99 & 2.501 & 2.17 & & \\
\hline & $\sigma_{\mathrm{R}}$ & 0.716 & 173.66 & 0.513 & 2.24 & & \\
\hline & $\mathrm{F}$ & 0.840 & 171.84 & 4.291 & 2.05 & & \\
\hline & $\mathrm{R}$ & 0.808 & 173.41 & 5.631 & 2.20 & & \\
\hline \multirow{4}{*}{ ن } & $\sigma$ & 0.718 & 123.60 & 0.170 & 0.70 & \multirow{4}{*}{9} & \multirow{4}{*}{$\begin{array}{c}\mathrm{H}, 3-\mathrm{Br}, 2-\mathrm{Cl}, 4-\mathrm{Cl}, \\
2-\mathrm{OH}, 4-\mathrm{OH}, \\
4-\mathrm{OCH}_{3}, 2-\mathrm{NO}_{2}, \\
4-\mathrm{NO}_{2}\end{array}$} \\
\hline & $\sigma^{+}$ & 0.728 & 123.62 & 0.311 & 0.68 & & \\
\hline & $\sigma_{\mathrm{I}}$ & 0.707 & 123.54 & 0.747 & 0.70 & & \\
\hline & $\sigma_{\mathrm{R}}$ & 0.718 & 132.75 & 0.464 & 0.69 & & \\
\hline
\end{tabular}




\begin{tabular}{|c|c|c|c|c|c|c|c|}
\hline & $\mathrm{F}$ & 0.769 & 123.77 & 0.231 & 0.52 & & \\
\hline & $\mathrm{R}$ & 0.822 & 123.75 & 0.454 & 0.50 & & \\
\hline \multirow{6}{*}{$\bigcup_{\infty}^{\infty}$} & $\sigma$ & 0.981 & 142.93 & 1.155 & 0.37 & \multirow{6}{*}{9} & \multirow{6}{*}{$\begin{array}{c}\mathrm{H}, 3-\mathrm{Br}, 2-\mathrm{Cl}, 4-\mathrm{Cl} \text {, } \\
\text { 2-OH, 4-OH, } \\
\text { 4-OCH }, 2-\mathrm{NO}_{2}, \\
4-\mathrm{NO}_{2}\end{array}$} \\
\hline & $\sigma^{+}$ & 0.982 & 142.93 & 1.791 & 0.36 & & \\
\hline & $\sigma_{\mathrm{I}}$ & 0.905 & 142.55 & 1.544 & 0.54 & & \\
\hline & $\sigma_{R}$ & 0.971 & 143.45 & 1.968 & 0.42 & & \\
\hline & $\mathrm{F}$ & 0.905 & 142.52 & 1.527 & 0.55 & & \\
\hline & $\mathrm{R}$ & 0.977 & 143.49 & 1.421 & 0.40 & & \\
\hline
\end{tabular}

$\mathrm{R}=$ correlation coefficient $\mathrm{I}=$ intercept; $\rho=$ slope; $\mathrm{s}=$ standard deviation; $\mathrm{n}=$ number of correlated derivatives

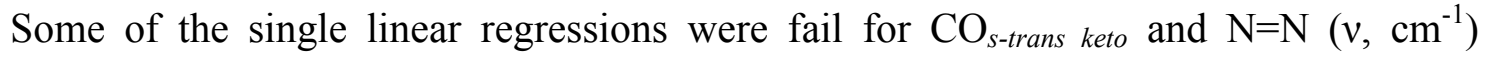
stretching frequencies of substituted styryl $(E)-4$-((2-oxopropyl) diazenyl) benzoic acid derivatives. While seeking the multi-regression analysis of the infrared group frequencies, they were satisfactorily correlated with $\sigma_{\mathrm{I}}$ and $\sigma_{\mathrm{R}}$ constants and F and R Swain Lupton's [30] constants. The generated multi-regression analysis equations are given in (2-9).

$$
\begin{gathered}
v \mathrm{CO}_{\text {acid }}\left(\mathrm{cm}^{-1}\right)=1712.81( \pm 2.675)+4.486( \pm 0.522) \sigma_{\mathrm{I}}+5.088( \pm 0.411) \sigma_{\mathrm{R}} \\
(R=0.965, \mathrm{n}=9, \mathrm{P}>95 \%) \\
v \mathrm{CO}_{\text {acid }}\left(\mathrm{cm}^{-1}\right)=1712.19( \pm 2.712)+5.832( \pm 0.537) \mathrm{F}+3.611( \pm 0.323) \mathrm{R} \\
(R=0.962, \mathrm{n}=9, \mathrm{P}>95 \%)
\end{gathered}
$$

$$
\begin{gathered}
v \mathrm{CO}_{\text {s-cis keto }}\left(\mathrm{cm}^{-1}\right)=1681.78( \pm 3.536)+13.639( \pm 6.906) \sigma_{\mathrm{I}}+13.639( \pm 6.906) \sigma_{\mathrm{R}} \\
(R=0.965, \mathrm{n}=9, \mathrm{P}>95 \%)
\end{gathered}
$$

$$
\begin{aligned}
& v \mathrm{CO}_{\text {s-cis keto }}\left(\mathrm{cm}^{-1}\right)=1681.42( \pm 36.995)+14.751( \pm 7.330) \mathrm{F}+7.278( \pm 4.412) \mathrm{R} \\
& (R=0.979, \mathrm{n}=9, \mathrm{P}>95 \%)
\end{aligned}
$$

$$
\begin{gathered}
v \mathrm{CO}_{\text {s-ttrans keto }}\left(\mathrm{cm}^{-1}\right)=1667.68( \pm 5.983)+3.051( \pm 1.683) \sigma_{\mathrm{I}}+14.624( \pm 1.963) \sigma_{\mathrm{R}} \\
(R=0.963, \mathrm{n}=9, \mathrm{P}>95 \%)
\end{gathered}
$$

$$
v \mathrm{CO}_{\text {s-cis keto }}\left(\mathrm{cm}^{-1}\right)=1668.81( \pm 6.039)+0.999( \pm 0.111) \mathrm{F}+12.342( \pm 1.721) \mathrm{R}
$$$$
(R=0.960, \mathrm{n}=9, \mathrm{P}>95 \%)
$$

$$
\begin{gathered}
v \mathrm{~N}=\mathrm{N}\left(\mathrm{cm}^{-1}\right)=1483.98( \pm 95.954)+153.112( \pm 18.735) \sigma_{\mathrm{I}}+128.816( \pm 14.714) \sigma_{\mathrm{R}} \\
(R=0.956, \mathrm{n}=9, \mathrm{P}>95 \%)
\end{gathered}
$$

$$
\begin{gathered}
v \mathrm{NH}_{2}\left(\mathrm{~cm}^{-1}\right)=1464.18( \pm 93.181)+201.78( \pm 18.481) \mathrm{F}+198.297( \pm 11.174) \mathrm{R} \\
(R=0.958, \mathrm{n}=9, \mathrm{P}>95 \%)
\end{gathered}
$$




\section{2. NMR spectral study}

In nuclear magnetic resonance spectra, the ${ }^{1} \mathrm{H}$ or the ${ }^{13} \mathrm{C}$ chemical shifts $(\delta$, ppm) depend on the electronic environment of the nuclei concerned. These chemical shifts of substituted styryl (E)-4-((2-oxopropyl) diazenyl) benzoic acid derivatives have been correlated with reactivity parameters. Thus the Hammett equation was used in the form as shown in (10).

$$
\log \delta=\log \delta_{0}+\rho \sigma
$$

where $\delta_{0}$ is the chemical shift of the corresponding parent compound.

\section{2. 1. ${ }^{1} \mathrm{H}$ NMR spectral study}

The ${ }^{1} \mathrm{H}$ NMR spectra of these synthesized substituted styryl (E)-4-((2-oxopropyl) diazenyl) benzoic acid derivatives under investigations were recorded in deuteriochloroform solution using tetramethylsilane (TMS) as internal standard. The chemical shifts of $(\delta, \mathrm{ppm})$ vinyl protons of these compounds have been assigned and tabulated in Table 1 . The results of statistical analysis [1-12,23-29] were presented in Table 2. From the Table 2, the correlation of $\mathrm{H} \alpha$ chemical shifts $(\delta, \mathrm{ppm})$ of the chalcones were satisfactory for Hammett $\sigma$, $\sigma^{+}, \sigma_{\mathrm{R}}$ constants and $\mathrm{R}$ parameter.

The Hammett $\sigma_{\text {I }}$ constant and $\mathrm{F}$ parameter were fail in correlation for these chemical shifts. Only the Hammett $\sigma_{R}$ constant gave satisfactory correlation with $\mathrm{H} \beta$ chemical shifts $(\delta$, ppm) of the chalcones. The remaining Hammett substituent constants, F and R parameters were fail in correlations. This is due to the inability of effect of substituents on the vinyl protons of the chalcones and is associated with the resonance conjugative structure as shown in Fig. 2. The correlation of methylene protons $(\delta, \mathrm{ppm})$ of the chalcones were fail in correlation with Hammett substituent constants and $\mathrm{F}$ and $\mathrm{R}$ parameters. The reason for failure in correlation was stated earlier and it is associated with the resonance conjugative structure as shown in Fig. 2. All correlations gave positive $\rho$ values. This means that the normal substituent effect operated in all systems.

Some of the single parameter correlations were fail for vinyl and methylene proton chemical shifts $(\delta, \mathrm{ppm})$ of substituted styryl $(E)-4-((2-0 x o p r o p y l)$ diazenyl) benzoic acid derivatives. While seeking the multi-regression analysis, these chemical shifts $(\delta$, ppm) were satisfactorily correlated with $\sigma_{\mathrm{I}}$ and $\sigma_{\mathrm{R}}$ constants and F and R Swain Lupton's [30] constants. The generated multi-regression analysis equations are given in (11-16).

$$
\begin{gathered}
\delta \mathrm{H} \alpha(\mathrm{ppm})=6.676( \pm 0.113)-0.042( \pm 0.021) \sigma_{\mathrm{I}}+0.622( \pm 0.175) \sigma_{\mathrm{R}} \\
(R=0.985, \mathrm{n}=9, \mathrm{P}>95 \%) \\
\delta \mathrm{H} \alpha(\mathrm{ppm})=6.614( \pm 0.129)+0.095( \pm 0.025) \mathrm{F}+0.440( \pm 0.154) \mathrm{R} \\
(R=0.979, \mathrm{n}=9, \mathrm{P}>95 \%) \\
\delta \mathrm{H} \beta(\mathrm{ppm})=6.944( \pm 0.217)+0.036( \pm 0.004) \sigma_{\mathrm{I}}+0.435( \pm 0.033) \sigma_{\mathrm{R}} \\
(R=0.951, \mathrm{n}=9, \mathrm{P}>95 \%) \\
\delta \mathrm{H} \beta(\mathrm{ppm})=6.869( \pm 0.216)+0.133( \pm 0.042) \mathrm{F}+0.295( \pm 0.021) \mathrm{R} \\
(R=0.949, \mathrm{n}=9, \mathrm{P}>90 \%)
\end{gathered}
$$




$$
\begin{gathered}
\delta \mathrm{CH}_{2}(\mathrm{ppm})=3.034( \pm 0.062)+0.221( \pm 0.128) \sigma_{\mathrm{I}}+0.162( \pm 0.011) \sigma_{\mathrm{R}} \\
(R=0.961, \mathrm{n}=9, \mathrm{P}>95 \%) \\
\delta \mathrm{CH}_{2}(\mathrm{ppm})=3.024( \pm 0.060)+0.250( \pm 0.120) \mathrm{F}+0.113( \pm 0.072) \mathrm{R} \\
(R=0.967, \mathrm{n}=9, \mathrm{P}>95 \%)
\end{gathered}
$$

\section{2. 2. ${ }^{13} \mathrm{C}$ NMR spectra}

In the present study, the chemical shifts $(\delta, \mathrm{ppm})$ of $\mathrm{CO}_{\text {acid, }}$ keto and vinyl carbons of the synthesized chalcones derivatives have been assigned and are presented in Table 1. Attempts have been made to correlate the above said carbon chemical shifts $(\delta$, ppm) with Hammett substituent constants, field and resonance parameters with the help of single and multiregression analyses to study the reactivity through the effect of substituents. The results of statistical analysis [1-12,23-29] are presented in Table 2. The $\delta \mathrm{CO}_{\text {acid }}$ chemical shifts (ppm) gave satisfactory correlations with Hammett $\sigma_{\mathrm{R}}$ substituent constants, $\mathrm{R}$ parameter. The remaining Hammett substituent constants and $\mathrm{F}$ parameters were fail in correlation. The correlation of $\delta \mathrm{CO}_{a c i d}$ and $\delta \mathrm{C} \alpha$ chemical shifts $(\delta, \mathrm{ppm})$ was fail in correlation for Hammett substituent constants and $\mathrm{F}$ and $\mathrm{R}$ parameters. The reason for failure in correlation was stated already and is associated with resonance conjugative structure as shown in Fig. 2 . The $\delta \mathrm{C} \beta$ chemical shifts $(\delta, \mathrm{ppm})$ of all ketones were satisfactorily correlated with Hammett substituent constants and F and R parameters. All correlations gave positive $\rho$ values. This means that the normal substituent effect operates in all systems.

Some of the single parameter correlations were fail for $\mathrm{CO}_{\text {acid, }}$ keto and vinyl carbons chemical shifts $(\delta, \mathrm{ppm})$ of substituted styryl $(E)-4-((2-0 x o p r o p y l)$ diazenyl) benzoic acid derivatives. While seeking the multi-regression analysis, these chemical shifts $(\delta, \mathrm{ppm})$ were satisfactorily correlated with $\sigma_{\mathrm{I}}$ and $\sigma_{\mathrm{R}}$ constants and F and R Swain Lupton's [30] constants. The generated multi-regression analysis equations are given in (17-24).

$$
\begin{aligned}
& \delta \mathrm{CO}_{a c i d}(\mathrm{ppm})=197.61( \pm 0.635)+2.971( \pm 1.261) \sigma_{\mathrm{I}}+1.014( \pm 0.075) \sigma_{\mathrm{R}} \\
& (R=0.953, \mathrm{n}=9, \mathrm{P}>95 \%) \\
& \delta \mathrm{CO}_{\text {acid }}(\mathrm{ppm})=197.64( \pm 0.608)+0.270( \pm 0.118) \mathrm{F}+1.383( \pm 0.093) \mathrm{R} \\
& (R=0.960, \mathrm{n}=9, \mathrm{P}>95 \%) \\
& \delta \mathrm{CO}_{\text {keto }}(\mathrm{ppm})=172.32( \pm 2.313)+2.886( \pm 0.415) \sigma_{\mathrm{I}}+6.123( \pm 2.3175) \sigma_{\mathrm{R}} \\
& (R=0.926, \mathrm{n}=9, \mathrm{P}>90 \%) \\
& \delta \mathrm{CO}_{\text {keto }}(\mathrm{ppm})=170.99( \pm 2.079)+5.367( \pm 0.413) \mathrm{F}+1.757( \pm 0.248) \mathrm{R} \\
& (R=0.947, \mathrm{n}=9, \mathrm{P}>90 \%) \\
& \delta \mathrm{C} \alpha(\mathrm{ppm})=123.75( \pm 0.745)-0.058( \pm 0.004) \sigma_{\mathrm{I}}+0.478( \pm 0.114) \sigma_{\mathrm{R}} \\
& (R=0.918, \mathrm{n}=9, \mathrm{P}>90 \%) \\
& \delta \mathrm{C} \alpha(\mathrm{ppm})=124.02( \pm 0.719)-0.590( \pm 0.412) \mathrm{F}+0.585( \pm 0.085) \mathrm{R} \\
& (R=0.947, \mathrm{n}=9, \mathrm{P}>90 \%) \\
& \delta \mathrm{C} \beta(\mathrm{ppm})=143.20( \pm 0.434)+0.544( \pm 0.084) \sigma_{\mathrm{I}}+1.479( \pm 0.665) \sigma_{\mathrm{R}} \\
& (R=0.977, \mathrm{n}=9, \mathrm{P}>90 \%)
\end{aligned}
$$




$$
\begin{gathered}
\delta \mathrm{C} \beta(\mathrm{ppm})=143.15( \pm 0.396)+0.760( \pm 0.078) \mathrm{F}+1.255( \pm 0.475) \mathrm{R} \\
(R=0.980, \mathrm{n}=9, \mathrm{P}>95 \%)
\end{gathered}
$$

\section{CONCLUSIONS}

A series containing nine substituted styryl (E)-4-((2-oxopropyl) diazenyl) benzoic acid derivatives were prepared and analyzed their purities by reported method. The infrared $\mathrm{CO}_{\text {acid }}, \mathrm{CO}_{\text {s-cis, keto }}, \mathrm{CO}_{\text {s-trans, keto }}$ and $\mathrm{N}=\mathrm{N}$ stretching frequencies $\left(\mathrm{v}, \mathrm{cm}^{-1}\right),{ }^{1} \mathrm{H}$ chemical shifts $(\delta, \mathrm{ppm})$ of vinyl, methylene protons, ${ }^{13} \mathrm{C}$ chemical shifts $(\delta, \mathrm{ppm})$ of $\mathrm{CO}_{\text {acid }}, \mathrm{CO}_{\text {keto }}$ and vinyl carbons were assigned and correlated with Hammett substituent constants and $\mathrm{F}$ and $\mathrm{R}$ parameters. The infrared $\mathrm{CO}_{a c i d}, \mathrm{CO}_{s-\text { cis, keto }}$ stretching frequencies $\left(\mathrm{v}, \mathrm{cm}^{-1}\right)$ were correlated satisfactorily. The $\mathrm{CO}_{\text {s-trans, keto }}$ stretching frequencies $\left(v, \mathrm{~cm}^{-1}\right)$ were correlated satisfactorily for Hammett $\sigma, \sigma^{+}, \sigma_{R}$ constants and R parameters. The ${ }^{1} \mathrm{H}$ chemical shifts of $\mathrm{H} \alpha(\delta, \mathrm{ppm})$ of vinyl protons were satisfactorily correlated with Hammett $\sigma, \sigma^{+}, \sigma_{R}$ constants and $R$ parameters. The $\mathrm{H} \beta(\delta$, ppm) of vinyl protons were satisfactorily correlated only with Hammett $\sigma_{\mathrm{R}}$ constant. The ${ }^{13} \mathrm{C}$ chemical shifts $(\delta, \mathrm{ppm})$ of $\mathrm{CO}_{\text {acid }}$ carbons were satisfactorily correlated with Hammett $\sigma_{\mathrm{R}}$ constants and $\mathrm{R}$ parameters. The vinyl $\mathrm{C} \beta(\delta$, ppm) carbon chemical shifts of prepared compounds were satisfactorily correlated with Hammett substituent constants, F and R parameters.

\section{References}

[1] G. Thirunarayanan, M. Suresh, International Letters of Chemistry, Physics and Astronomy 4 (2014) 1-11.

[2] R. Arulkumaran, S. Vijayakumar, R. Sundararajan, S. P. Sakthinathan, D. Kamalakkannan, R. Suresh, K. Ranganathan, G. Vanangamudi, G. Thirunarayanan, International Letters of Chemistry, Physics and Astronomy, 4 (2012) 17-38.

[3] S. John Joseph, R. Arulkumaran, D. Kamalakkannan, S. P. Sakthinathan, R. Sundararajan, R. Suresh, S. Vijayakumar, K. Ranganathan, N. Kalyanasundaram, G. Vanangamudi, G. Thirunarayanan, International Letters of Chemistry, Physics and Astronomy, 4 (2014) 48-65.

[4] R. Arulkumaran, S. Vijayakumar, R. Sundararajan, S. P. Sakthinathan, D. Kamalakkannan, R. Suresh, K. Ranganathan, P. R. Rajakumar, G. Vanangamudi, G. Thirunarayanan, International Letters of Chemistry, Physics and Astronomy, 5 (2013) 21-38.

[5] S. P. Sakthinathan, R. Suresh, V. Mala, K. Sathiyamoorthi, D. Kamalakkannan, K. Ranganathan, R. Arulkumaran, S. Vijayakumar, R. Sundararajan, G. Vanangamudi, G. Thirunarayanan, International Letters of Chemistry, Physics and Astronomy, 6 (2013) 77-90.

[6] G. Thirunarayanan, G. Sekar, International Letters of Chemistry, Physics and Astronomy, 10(1) (2013) 18-34. 
[7] S. John Joseph, R. Arulkumaran, D. Kamalakkannan, S. P. Sakthinathan, R. Sundararajan, R. Suresh, S. Vijayakumar, K. Ranganathan, N. Kalyanasundaram, G. Vanangamudi, G. Thirunarayanan, International Letters of Chemistry, Physics and Astronomy, 4 (2014) 48-65.

[8] G. Thirunarayanan, International Letters of Chemistry, Physics and Astronomy, 5 (2014) 89-98.

[9] G. Thirunarayanan, International Letters of Chemistry, Physics and Astronomy, 4 (2014) 109-116.

[10] N. Kalyanasundaram, S. P. Sakthinathan, R. Suresh, D. Kamalakkannan,

S. John Joseph, G. Vanangamudi, G. Thirunarayanan, International Letters of Chemistry, Physics and Astronomy, 9 (2014) 23-47.

[11] G. Thirunarayanan, M. Gopalakrishnan, G. Vanangamudi, Spectrochim. Acta, 67A (2007) 1106-1117.

[12] K. Ranganathan, R. Suresh, D. Kamalakkannan, R. Arulkumaran, R. Sundararajan, S. P. Sakthinathan, S. Vijayakumar, G. Vanangamudi, K. Thirumurthy, P. Mayavel, G. Thirunarayanan, International Letters of Chemistry, Physics and Astronomy, 4 (2012) 66-75.

[13] G. K. Dass, Indian J. Chem. 40(A)(1) (2001) 23-29.

[14] X. Li, X. Wu, L. Huang, Molecules, 14 (2009)5349-5361.

[15] C. Pellerin, I. Pelletier, Lab Plus International, Reed Elsevier Publicaitons, UK, 19 (2005) 108-112.

[16] Y. H. Wang, J. W. Zou, B. Zhang, Y. X. Lu, H. X. Jin, Q. S. Yu, J. Mol. Struct. (Theochem) 755(1-2) (2005) 31-37.

[17] X. Liu, M. L. Go, Bioorg. Med.Chem. 14(1) (2006) 153-163.

[18] R. Arulkumaran, R. Sundararajan, G. Vanangamudi, M. Subramanian, K. Ravi, V. Sathiyendiran, S. Srinivasan, G. Thirunarayanan, IUP J. Chem. 3(1) (2010) 82-98.

[19] J. Deng, T. Sanchez, Q. A. M. Lalith, Bioorg. Med. Chem. 15(14) (2007) 4985-5002.

[20] G. Thirunarayanan, J. Indian Chem. Soc. 84 (2008) 447-451.

[21] G. Thirunarayanan, S. Surya, S. Srinivasan, G. Vanangamudi, V. Sathiyendiran, Spectrochim. Acta. 75A (2010) 152-156.

[22] R. Sundararajan, R. Arulkumaran, S. Vijayakumar, D. Kamalakkannan, R. Suresh, S. John Joseph, K. Ranganathan, SP. Sakthinathan, G. Vanangamudi, G. Thirunarayanan, International Letters of Chemistry, Physics and Astronomy, 1, 67-73, 2014.

[23] S. John Joseph, D. Kamalakkannan, R. Arulkumaran, S. P. Sakthinathan, R. Suresh, R. Sundararajan, S. Vijayakumar, K. Ranganathan, G. Vanangamudi, G. Thirunarayanan, International Letters of Chemistry, Physics and Astronomy, 5, 99-123, 2014.

[24] G. Thirunarayanan, K. G. Sekar, International Letters of Chemistry, Physics and Astronomy, 10(1), 18-34, 2013. 
[25] G. Thirunarayanan, S. Pazhamalai, K. G. Sekar, International Letters of Chemistry, Physics and Astronomy, 8 (2014) 38-46.

[26] D. Kamalakkannan, G. Vanangamudi, R. Arulkumaran, K. Thirumurthy, P. Mayavel, G. Thirunarayanan, Elixir Org. Chem., 46 (2012) 8157-8166.

[27] A. R. Trivedi, D. K. Dodiya, N. R. Ravat, V. H. Shah, Arkivoc, 11 (2008) 131-141.

[28] R. Arulkumaran, G. Vanangamudi, D. Kamalakkannan, R. Sundararajan,S. Vijayakumar, K. Thirumurthy, P. Mayavel, G. Thirunarayanan, Annals Unversitat. Mariae Curie-Skłodowska Lublin - Polonia, Sec.AA, 67 (2012) 45-77

[29] G. Thirunarayanan, K. G. Sekar, J. Taibah Univ. Sci, 2013. DOI: $10.1016 /$ j.jtusci.2013.11.003.

[30] Swain C. G., Lupton Jr., E. C. J. Am. Chem. Soc. 90 (1968) 4328-4337. 